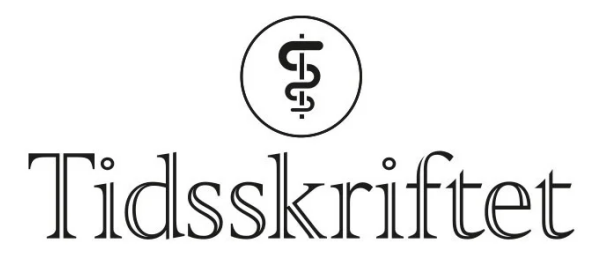

DEN NORSKE LEGEFORENING

\title{
Nyoppdaget mekanisme for reparasjon av muskelskader
}

FRA ANDRE TIDSSKRIFTER

HAAKON B. BENESTAD

Universitetet i Oslo

Muskelskader etter harde eksentriske kontraksjoner, slike man blir støl av, kan tilheles uten muskelstamceller.

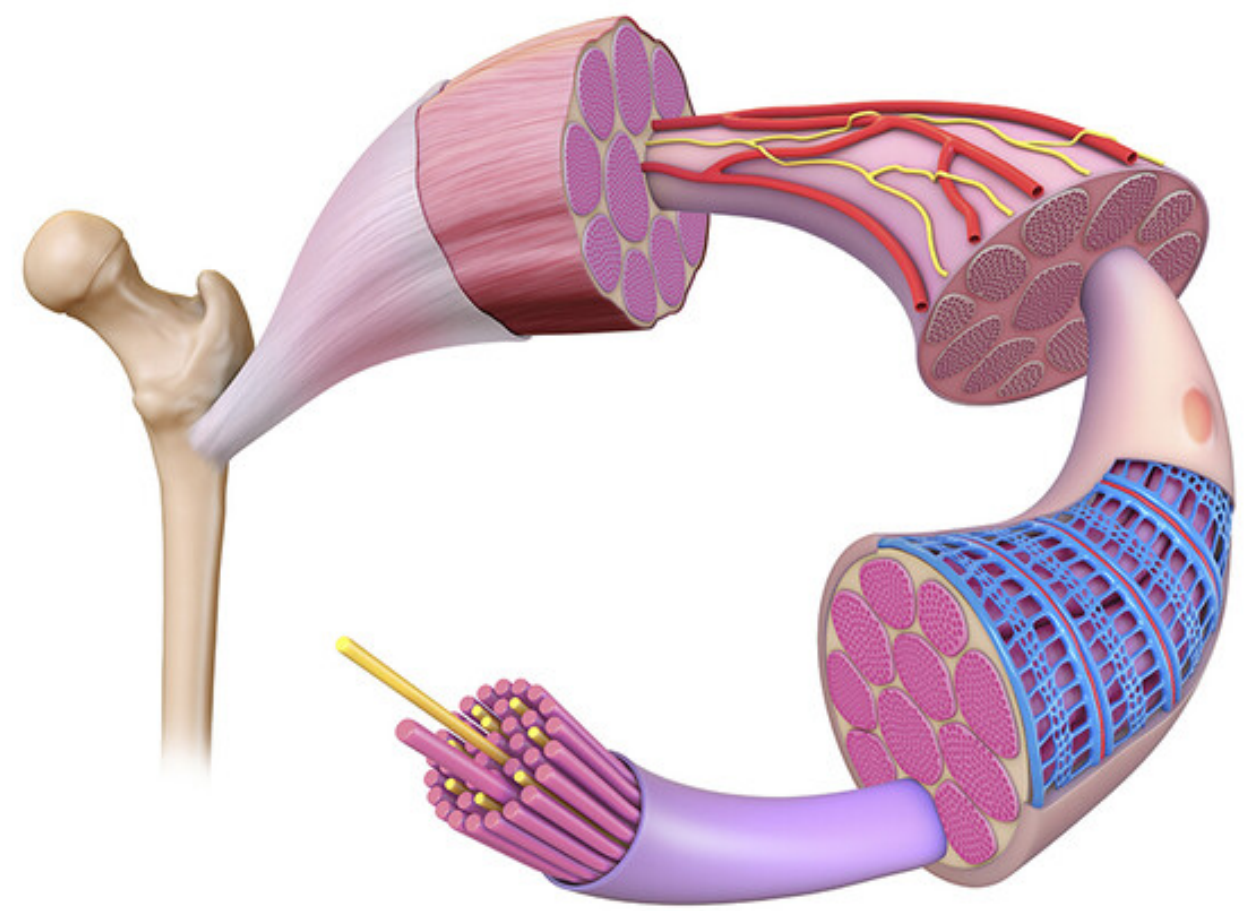

Skjelettmuskelfiber hos menneske. Illustrasjon: Maurizio De Angelis / Science Photo Library

Både økning av muskelstyrke ved styrketrening og reparasjon av skader i

skjelettmuskulatur skyldes gjerne inkorporering av muskelstamceller i muskelfibrene.

Muskelfibrene er multinukleære muskelceller med 5-10 cellekjerner per 100 mikrometer 
fiberlengde, der kjernene styrer proteinsyntesen lokalt, i et lite cytoplasmavolum. Muskelstamcellene er satellittcellene som ligger tett inntil muskelfibrene.

I en ny studie har forskere påvist en reparasjonsmekanisme som kunne brukes etter lettere muskelskader (11). Slike skader opptrer ved bl.a. belastende, eksentrisk muskelkontraksjon, dvs. strekk av kontrahert muskel, som ved å løpe nedoverbakke.

Tidligere dyrefors $ø \mathrm{k}$ har vist at ruptur i muskelcellemembranen ble reparert innen sekunder. Den nyoppdagede reparasjonsmekanismen for selve sarkomerskaden under rupturen beror på vandring av muskelcellekjerner til skadestedet via de vanlige intracellulære transportveiene som bruker mikrotubuli og dynein. I disse skadelokaliserte cellekjernene ble gener transkribert, noe som førte til lokal syntese av proteinene som trengs i reparasjonen. Ved spesialfarging ble reparasjonsprosessen fulgt med mikroskopi. Markante skader hos forsøksmus ble påvist etter 5 og 24 timer, men var svekket og på god vei til å forsvinne 48 timer etter treningsaktivitet - og altså en reparasjon uten inkorporering av satellittceller i muskelfibrene.

Reparasjonsmekanismen ble påvist både i ex vivo-fors $ø \mathrm{k}$ med bruk av opphengte, utstrakte og elektrisk stimulerte musemuskler og i in vivo-fors $ø \mathrm{k}$ med mus eller fors $\emptyset$ kspersoner som løp på hellende tredemølle. Trenede mus hadde mindre skader enn utrente mus. Skader ble også påvist i muskelbiopsier fra unge forsøkspersoner.

- Denne studien er et imponerende arbeid der forskerne har fulgt opp og bekreftet funn med flere ulike metoder, sier Gøran Paulsen, som er professor i muskelfysiologi ved Norges idrettshøgskole. Det mest oppsiktsvekkende funnet er bevegelsen av myokjerner til myofibrillære skadeområder. Dette vil vi studere i våre egne, aktuelle humanstudier av eksentrisk muskelarbeid, sier han.

- Siden vi vet at satellittcellene er viktige i reparasjonen av større muskelcelleskader, vil neste steg være å få bedre forståelse av interaksjonen mellom myokjernene som ble rekruttert til skadestedene, og donasjon av nye kjerner fra satellittcellene, som i den klassiske reparasjonsmodellen. De nye funnene sammenfaller faktisk godt med våre tidligere humanstudier med muskelsvakhet i timene etter utmattende trening, sier Paulsen.

\section{LITTERATUR}

1. Roman W, Pinheiro H, Pimentel MR et al. Muscle repair after physiological damage relies on nuclear migration for cellular reconstruction. Science 2021; 374:355-9. [PubMed][CrossRef]

Publisert: 4. januar 2022. Tidsskr Nor Legeforen. DOI: 10.4045/tidsskr.21.0806

(C) Tidsskrift for Den norske legeforening 2023. Lastet ned fra tidsskriftet.no 26. april 2023. 